\title{
Reply to An Investigation Into the Serum Thioredoxin, Superoxide Dismutase, Malondialdehyde, and Advanced Oxidation Protein Products for Patients with Breast Cancer
}

\author{
Nedret Kılıç, PhD ${ }^{1,2}$ \\ ${ }^{1}$ Faculty of Medicine, Gazi University, Besevler, Ankara, Turkey; ${ }^{2}$ Faculty of Health Sciences, Atilim University, İncek, \\ Ankara, Turkey
}

\section{TO THE EDITORS:}

Our study was undertaken to investigate the oxidative stress and antioxidant status in the blood samples of patients with breast cancer. Malondialdehyde (MDA) currently is used to demonstrate lipid peroxidation and oxidative stress. In many studies similar to our study, serum levels of MDA have been measured in patients with breast cancer. ${ }^{1-4}$ Our study particularly aimed to note the significant change in thioredoxin (Trx) and advanced oxidation protein product (AOPP) levels.

The association between oxidative stress and cancer pathogenesis is important. In the light of hypothetical assessments and scientific findings, it cannot be said that MDA in oxidative stress is insignificant.

As specified, the aim of this letter to the editor was not to be critical of our study. In our opinion, the content of the letter shows a misunderstanding of our general study, and the authors only briefly reviewed MDA. Indeed, the most important point highlighted in the letter is the uncertainty or unreliability of MDA as a cancer biomarker. However, our study in no way claimed that MDA is a specific biomarker.

The preanalytical and analytical problems mentioned in the letter about MDA are a concern with almost all available research kits. However, in our study, serum samples were collected under the same conditions and in the same time slot to minimize preanalytical errors, and MDA levels were measured with the most common method. ${ }^{5}$ In brief, the criticisms in the letter are not considering the methodology of our study.

In conclusion, we believe the content of the letter can be considered as a brief review or analysis of MDA independently of our study.

\section{REFERENCES}

1. Karki K, Pande D, Negi R, Khanna S, Khanna RS, Khanna HD. Expression of serum toll-like receptor 9 and oxidative damage markers in benign and malignant breast diseases. DNA Cell Biol. 2014; 33:630-6.

2. Baskic D, Popovic S, Bankovic D, Arsovic A, Vukovic V, Zelen I, Djurdjevic P. Evaluation of inflammatory biomarkers as helping diagnostic tool in patients with breast cancer. Cancer Biomark. 2014; 14:401-8.

3. Gupta RK, Patel AK, Kumari R, Chugh S, Shrivastav C, Mehra S, Sharma AN. Interactions between oxidative stress, lipid profile and antioxidants in breast cancer: a case control study. Asian Pac J Cancer Prev. 2012; 13:6295-8.

4. Pande D, Negi R, Khanna S, Khanna R, Khanna HD. Vascular endothelial growth factor levels in relation to oxidative damage and antioxidant status in patients with breast cancer. $J$ Breast Cancer. 2011; 14:181-4.

5. Yoshioka T, Kawada K, Shimada T, Mori M. Lipid peroxidation in maternal and cord blood protective mechanism against activatedoxygen toxicity in the blood. Am J Obstet Gynecol. 1979; $135: 372-6$.
(C) Society of Surgical Oncology 2017

First Received: 10 October 2017;

Published Online: 30 October 2017

N. Kılıç, PhD

e-mail: nedretkilic73@gmail.com 